\title{
Bilateral retinal detachment - when the kidney meets the eye
}

\author{
Descolamento de retina bilateral - quando o rim afeta o olho

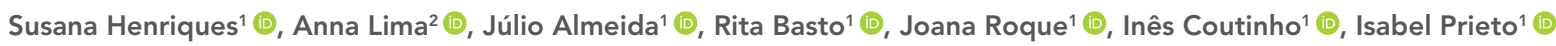 \\ Ophthalmology Department, Hospital Professor Doutor Fernando Fonseca, EPE, Portugal. \\ ${ }_{2}^{2}$ Nephrology Department, Hospital Professor Doutor Fernando Fonseca, EPE, Portugal.
}

Henriques S, Lima A, Almeida J, Basto R, Roque J, Coutinho I, Prieto I. Bilateral retinal detachment - when the kidney meets the eye. Rev Bras Oftalmol. 2021:80(5):e0045.

https://doi.org/10.37039/1982.8551.20210045

Keywords:

Retinal detachment; Nephrotic syndrome; Renal insufficiency,

chronic

Descritores:

Descolamento da retina; Síndrome nefrótica; Insuficiência renal crônica

Received on: Apr 06, 2021

Accepted on:

Jul 31, 2021

Corresponding author: Susana Henriques
Department of Ophthalmology, Hospital Professor Doutor Fernando Fonseca EPE, Portugal

E-mail: susanapintohenriques@gmail.com

Institution: Hospital Professor Doutor Fernando Fonseca, EPE, Portugal.

Conflict of interest: the authors declare no conflict of interest.

Financial support: the authors received no financial support for this work.

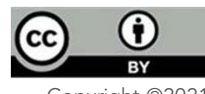

Copyright (C2021

\begin{abstract}
Exudative retinal detachment occurs when fluid accumulates between the neurosensory retina and the retinal pigment epithelium. Ocular diseases or multisystem conditions such as nephrotic syndrome may lead to exudative retinal detachment. This report describes a case of nephrotic syndrome secondary to minimal change disease, anasarca and bilateral serous macular detachment in an adult patient. A 75-year-old male patient presented to the emergency department with generalized edema, asthenia, and visual impairment. Medical history included a recent diagnosis of nephrotic syndrome secondary to minimal change disease, which had been controlled with corticosteroid therapy. At presentation, best corrected visual acuity was 20/100. Slit-lamp examination revealed xanthelasmas and mild bilateral eyelid edema and chemosis. Dilated fundus examination confirmed bilateral macular detachment. The patient did not respond to diuretic therapy. Ttherefore, hemodialysis was started. Two months later, visual acuity improved to 20/25 and near normal restoration of retinal anatomy was achieved, with concurrent remission of proteinuria. Exudative retinal detachment is a multifactorial condition. However, in diseases associated with severe hypoalbuminemia, such as nephrotic syndrome, low oncotic pressure in choroidal vessels and high interstitial pressure in the choroid may explain retinal detachment. Patients with chronic kidney disease carry a high risk of ophthalmic disease development. Several mechanisms that affect ocular vessels, the retina and the choroid are thought to be involved. A multidisciplinary approach is crucial to resolve the ophthalmic condition and improve overall health.
\end{abstract}

\section{RESUMO}

O descolamento de retina exsudativo ocorre quando o fluido se acumula entre a retina neurossensorial e o epitélio pigmentado da retina. Patologias oculares isoladas ou doenças multissistêmicas, como a síndrome nefrótica, podem levar ao descolamento de retina exsudativo. Apresenta-se aqui o caso de um adulto com síndrome nefrótica por doença de lesões mínimas, anasarca e descolamento de retina exsudativo macular bilateral. Trata-se de um homem de 75 anos de idade, que recorreu ao serviço de urgência com edema generalizado, astenia e diminuição da acuidade visual. Os antecedentes pessoais incluíam diagnóstico recente de síndrome nefrótica secundária à doença de lesões mínimas, em uso de corticoterapia. Na apresentação, a melhor acuidade visual corrigida era 20/100. A biomicroscopia revelou xantelasmas, edema palpebral leve e quemose nos dois olhos. Fundoscopia mostrou descolamento macular bilateral. $O$ doente iniciou diuréticos com pouca resposta clínica, tendo sido adicionada hemodiálise. Verificou-se melhora da acuidade visual para 20/25 e restauração quase total da anatomia da retina 2 meses após o início do tratamento, coincidindo com a remissão da proteinúria. A fisiopatologia dos descolamentos de retina exsudativos é multifatorial, mas, em doenças com hipoalbuminemia grave, como a síndrome nefrótica, a baixa pressão oncótica e a alta pressão intersticial na coroide podem explicar o descolamento macular exsudativo. Doentes com doença renal crônica constituem um grupo de risco para o desenvolvimento de doença ocular, envolvendo vários mecanismos que afetam vasos, retina e coroide. Uma abordagem multidisciplinar é crucial para a melhoria da doença oftalmológica e do estado geral do doente. 


\section{INTRODUCTION}

Exudative retinal detachment (ERD) occurs when fluid accumulates between the neurosensory retina (NSR) and the retinal pigment epithelium (RPE) in the absence of retinal tears and/or vitreoretinal traction. Subretinal exudation is thought result from changes in choroidal vascular perfusion and permeability or from impaired pump activity in the RPE, which lead to fluid accumulation in the subretinal space (SRS). ${ }^{(1)}$ Other ocular or multisystem conditions such as vascular, inflammatory, or neoplastic diseases may also play a role in ERD. ${ }^{(1)}$

The prevalence of eye diseases and visual impairment in patients with chronic kidney disease (CKD) is high, especially in the presence of concurrent comorbidities, such as diabetic retinopathy, hypertensive retinopathy or age-related macular disease (AMD). ${ }^{(2,3)}$ Associations between ERD and CKD have also been reported in patients undergoing hemodialysis ${ }^{(4,5)}$ and in some patients with nephrotic syndrome (NS), particularly in cases secondary to diabetes and hypertension. ${ }^{(6,7)}$ Nephrotic syndrome is characterized by severe proteinuria (>3.5 g/dL/24 hour), hypercholesterolemia and hypoalbuminemia, peripheral edema and fluid overload. ${ }^{(8)}$ Diabetic nephropathy, focal segmental glomerulosclerosis, membranous nephropathy and minimal change disease (MCD) are common causes of NS in adult patients. ${ }^{(8)}$

This report describes a case of MCD and bilateral serous macular detachment in an adult patient.

\section{CASE REPORT}

A 75-year-old male patient presented to the emergency department with generalized edema (limbs, neck, periorbital and conjunctiva), asthenia and visual impairment. Medical history included hypertension and a recent diagnosis of NS secondary to biopsy-confirmed MCD, which had been controlled with corticosteroids the month before. Laboratory workup revealed acute kidney injury (serum creatinine $4 \mathrm{mg} / \mathrm{dL}$ ), severe proteinuria $(6.5 \mathrm{~g} / \mathrm{dL}$ ) and hypoalbuminemia $(1.44 \mathrm{~g} / \mathrm{dL})$, confirming the presence of active disease. Pleural effusion and ascites were detected in chest radiographs and abdominal ultrasound, respectively. Serologic screening, autoimmune disease tests and kidney ultrasound findings were unremarkable. Initial routine ophtalmic exam revealed best corrected visual acuity (BCVA) of 20/100 in both eyes (OU), xanthelasmas and bilateral mild eyelid edema and chemosis (slit-lamp examination; Figures 1A to 1D). Dilated fundus examination revealed bilateral macular detachment (Figures 2A and $2 \mathrm{C}$ ), with no signs of hypertensive retinopathy, vitreoretinal traction and/or peripheral retinal tears. Spectraldomain optical coherence tomography (SD-OCT) revealed dome-shaped macula with serous macular detachment and cystoid edema in OU, but no other intraretinal abnormalities (Figures 2B to 2D). Peripapillary nerve fiber layer (pNFL) and choroidal thickness were normal in OU. Diuretic therapy was implemented. However, the patient did not respond, and hemodialysis was initiated to improve edema control. Progressive volume control and kidney function recovery were achieved. Therefore, the patient was discharged, and steroid therapy prescribed. Follow-up assessment one month later revealed BCVA improvement (20/25 in OU) and restoration of near normal retinal anatomy on dilated fundus examination (Figures $2 \mathrm{E}$ and $2 \mathrm{G}$ ) and SD-OCT (Figures $2 \mathrm{~F}$ to $2 \mathrm{H}$ ). These findings were concurrent with remission of proteinuria and kidney disease control. Previously undetected subretinal drusenoid deposits were seen in both maculas.

\section{DISCUSSION}

Minimal change disease accounts for $70 \%$ to $90 \%$ of cases of idiopathic NS in children. However, adult patients are less commonly affected (10\% to $15 \%$ of cases). ${ }^{(9)}$ This glomerular disorder often manifests as a primary renal disease. However, associations with other conditions, such as viral infections, allergies and non-steroidal anti-inflammatory therapy have been reported in a minority of cases. The pathophysiology of the condition has not been fully determined. Examination of renal biopsy specimen slides using light microscopy often fails to reveal obvious glomerular lesions. However, podocyte foot 


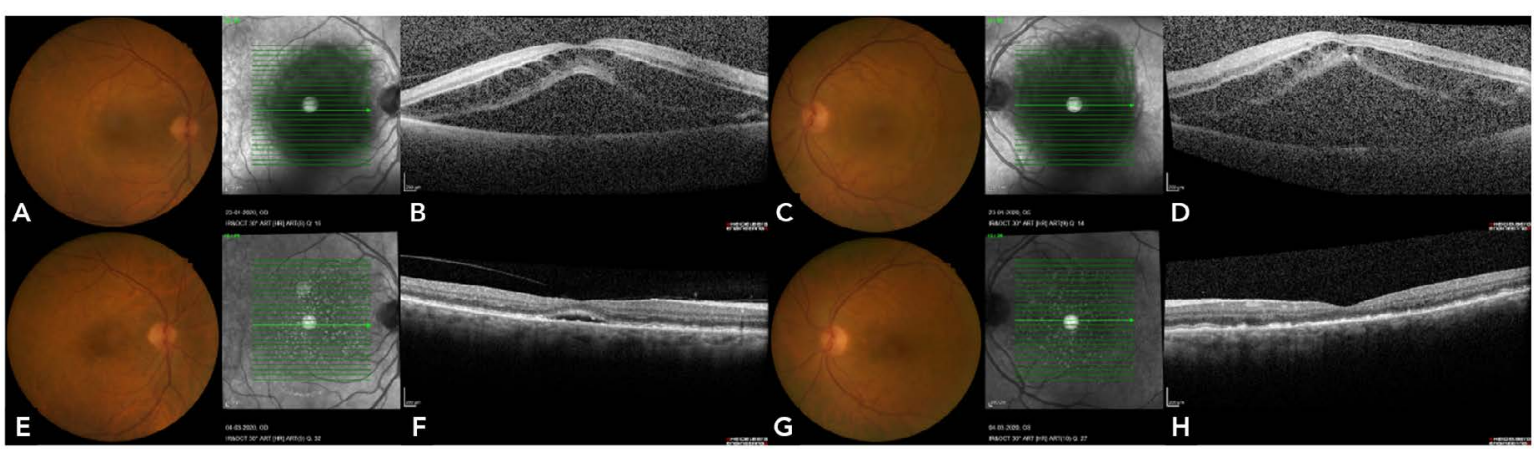

Figure 2. Fundus photographs and spectral-domain optical coherence tomography images acquired prior to (top) and following one month (bottom) of treatment. Macular detachment can be seen in fundus photographs of the right $(A)$ and the left $(C)$ eye. Dome-shaped macula with serous macular detachment and cystoid edema can be seen in optical coherence tomography images of the right (B) and the left eye (D). Cystoid edema and subretinal fluid resolution can be seen in post-treatment fundus photographs and optical coherence tomography images ( $E$ to $H$ ).

process effacement is typically seen on electron microscopy. ${ }^{(9)}$ Minimal change disease tends to coincide with the sudden onset of NS, indicated by severe proteinuria, minimal hematuria, hypoalbuminemia, hypercholesterolemia, edema, and hypertension. Prednisone is the firstline therapy, but other immunosuppressive drugs can be used in frequent relapsers, steroid-resistant or steroid-dependent patients. The prognosis in less favorable in adult patients with acute renal failure.

Exudative retinal detachment is often associated with other ocular retinal and/or choroidal diseases, ${ }^{(1)}$ such as diabetic retinopathy (DR), central serous chorioretinopathy $(\mathrm{CSC})$, posterior scleritis and intraocular tumors. Systemic causes $^{(1)}$ include the Vogt-Koyanagi-Harada (VKH) syndrome, toxemia of pregnancy, malignant hypertension, and CKD, which are often associated with hemodialysis and/or corticosteroid therapy. . $^{(5,7)}$

The RPE and the tight junctions of retinal capillary endothelial cells form the outer and inner blood-retinal barrier (BRB) respectively. The integrity of the BRB barrier is crucial to maintain the retina in normal, dry conditions. ${ }^{(10,11)}$ In theory, diseases that lead to outer or inner BRB breakdown and increase the permeability of choroidal capillaries may cause subretinal fluid accumulation. ${ }^{(10,11)}$ However, several mechanisms of adhesion of the NSR to the RPE ensure directional fluid transport from the RPE to the choroid, including active and passive transport across the RPE and pressure gradients between the vitreous, the retina and the choroid (intraocular pressure, plasma oncotic pressure and hydrostatic pressure, respectively). The higher oncotic pressure in the choroid relative to the vitreous maintains fluid dynamics and promotes the outward flow of water. ${ }^{(1,1,12)}$

Serum albumin is the most important plasma protein and a major determinant of oncotic pressure in the circulatory system. Low oncotic pressure in choroidal vessels in response to hypoalbuminemia facilitates the outflow of water from the intravascular to the interstitial space, increasing the hydrostatic pressure in the choroidal interstitium. ${ }^{(13)}$ Hence, in diseases associated with severe hypoalbuminemia such as NS, this mechanism may explain retinal detachment in some patients. Few isolated cases of ERD in hypoalbuminemic patients have been reported to date. These include one case of protein-losing enteropathy in a 47-year-old female patient with serum albumin levels of $1.4 \mathrm{~g} / \mathrm{dL}$ and bilateral ERD (Venkatramani et al.), ${ }^{(14)}$ one case of NS secondary to MCD in a 24-year-old female patient who developed bilateral ERD responsive to diuretic therapy (De Benedetto et al. (15) and one case of ERD in a 52-year-old patient with NS secondary to plasmacytoma (Hager et al.).. ${ }^{(16)}$ The patient described in this case report had severe hypoalbuminemia and other causes of ERD could be excluded, given serologic screening, autoimmune disease test and ophthalmic imaging findings were not consistent with infectious diseases, inflammatory conditions or diabetic or hypertensive retinopathy. Also, at the time of presentation, the patient had not yet started hemodialysis, which is often associated with ERD. Corticosteroid therapy and central serous chorioretinopathy (CSC) are common causes of serous macular detachment, the latter affecting predominantly middle-aged males. ${ }^{(1)}$

Exudative retinal detachment is a multifactorial condition. In the case described, two major factors may have accounted for subretinal fluid accumulation: reversal of pressure gradients from the choroid and the retina in response to severe hypoalbuminemia and drop in oncotic pressure induced by RPE ion pump dysfunction, possibly induced by the multiple subretinal drusenoid deposits seen at the level of the RPE on OCT images. 
Exudative retinal detachment therapy should be focused primarily on resolution of the underlying systemic disease. Corticosteroids are the first-line therapy for patients with NS, particularly in cases associated with MCD. Second-line treatment alternatives include cyclophosphamide and/or cyclosporine. ${ }^{(17)}$ Indeed, two months after initiation of treatment with corticosteroids and diuretics, functional and structural changes had been reverted to almost normality and concurrent remission of proteinuria was achieved.

In conclusion, patients with CKD carry a high risk of ophthalmic disease development. Multidisciplinary assessment by ophthalmologists, nephrologists and internists is vital for prompt diagnosis and therapeutic decision making in order to prevent severe visual dysfunction.

\section{REFERENCES}

1. Amer $\mathrm{R}, \mathrm{Nalcı} \mathrm{H}$, Yalçındağ N. Exudative retinal detachment. Surv Ophthalmol. 2017;62(6):723-69.

2. Wong CW, Lamoureux EL, Cheng CY, Cheung GC, Tai ES, Wong TY, et al. Increased burden of vision impairment and eye diseases in persons with chronic kidney disease - a population-based study. EBioMedicine. 2016;5:193-7.

3. Grunwald JE, Alexander J, Maguire M, Whittock R, Parker C, McWilliams K, et al.; CRIC Study Group. Prevalence of ocular fundus pathology in patients with chronic kidney disease. Clin J Am Soc Nephrol. 2010;5(5):867-73.

4. Donald J, Gass M. Bullous retinal detachment and multiple retinal pigment epithelial detachments in patients receiving hemodialysis. Graefe's Arch Clin Exp Ophthalmol. 1992;230(5):454-8.
5. Troiano P, Buccianti G. Bilateral symmetric retinal detachment and multiple retinal pigment epithelial detachments during haemodialysis. Nephrol Dial Transplant. 1998;13(8):2135-7

6. Bilge AD, Yaylali SA, Yavuz S, Simsek IB. Bilateral serous macular detachment in a patient with nephrotic syndrome. Retin Cases Brief Rep. 2018;12(3):260-2.

7. Desatnik HR, Gutman FA. Bilateral exudative retinal detachment complicating systemic corticosteroid therapy in the presence of renal failure. Am J Ophthalmol. 1996;122(3):432-4.

8. Radhakrishnan J, Appel GB. Glomerular disorders and nephrotic syndromes. In: Goldman L, Schafer A. Goldman-Cecil medicine. New Saunders; 2020 p. 753-763.e2.

9. Kasper D, Hauser S. JJ. Harrison's Principles of Internal Medicine. 19th ed. McGraw-Hill Education; 2015.

10. Cunha-Vaz J, Bernardes R, Lobo C. Blood-retinal barrier. Eur J Ophthalmol. 2011;21 Suppl 6:3-9.

11. Marmor MF. Mechanisms of normal retinal adhesion. In: Wilkinson C, Hinton D, Sadda S, Wiedemann P. Ryan's retina. 6th ed. Amsterdan: Elsevier; 2018. p. 504-21.

12. Ghazi NG, Green WR. Pathology and pathogenesis of retinal detachment. Eye (Lond). 2002;16(4):411-21.

13. Perico N, Remuzzi A, Remuzzi G. Pathophysiology of proteinuria. In: Lu AS, Chertow GM, Mbbch VL, Marsden PA, Skorecki K. Brenner and Rector's The Kidney. 11th ed. Amsterdan: Elsevier; 2020. p. 978-1006.e9.

14. Venkatramani J, Gottlieb JL, Thomassen TS, Multari A. Bilateral serous retinal detachment due to protein-losing enteropathy. Arch Ophthalmol. 2004;122(7):1067-70.

15. De Benedetto U, Pastore MR, Parodi MB, Bandello F, Pierro L. Retinal involvement in nephrotic syndrome secondary to minimal change disease. Eur J Ophthalmol. 2012;22(5):843-5.

16. Hager A, Wiegand W. Bilaterale seröse abhebung der neurosensorischen retina und des retinalen pigmentepithels mit riss des peripheren pigmentepithels. Ophthalmologe. 2006;103(11):966-70.

17. Kodner C. Diagnosis and management of nephrotic syndrome in adults. Am Fam Physician. 2016;93(6):479-85. 